\title{
The Analysis of Consincing Money Deposits in The State Court As A Form of Accountability of Land Liberation Land Loading In Sumatera Toll Road In Kalianda State Court
}

\author{
Dilla Nandya Oksitania ${ }^{1 *}$, Erlina B ${ }^{2}$, Yulia Hesti ${ }^{3}$ \\ ${ }^{123}$ Bandar Lampung University \\ Email: dillanandya03@gmail.com \\ *corresponding author
}

Received : 15 Apr 2021 | Revised : 23 May 2021 | Accepted : 29 May 2021 | Published : 10 Jun 2021

\begin{abstract}
Land is the most important element for humans to live, this is because land is a place where natural and man-made resources grow and are also built. Indonesia even regulates land ownership through this Land Law so that land use or management can be carried out carefully in the present and in the future. Land issue is a problem that concerns the most basic rights of the people. If the person in possession of the receivable refuses payment from the debtor, then the party owed can make cash payment of the debt by offering a payment made by the bailiff accompanied by 2 (two) witnesses. If the debtor refuses to receive payment, the money is deposited in the cash registrar of the District Court as a deposit / consignment. The offer and safekeeping must be legalized by a judge's order. By carrying out a consignment, it will be freed from the obligation as the debtor, because a consignment can be equated with making payments. However, all this must be done in a manner regulated by statutory regulations. KThe signaling was carried out after the deliberation mechanism which was supposed to be a means of finding a middle way in determining the amount of compensation often failed to reach an agreement. the consignment was carried out so that government projects for the sake of continued progress.
\end{abstract}

Keywords: Consignment, Settlement of Land Acquisition Loss, Sumatra Toll Road

\section{INTRODUCTION}

Land is the most important element for humans to live, this is because land is a place where natural and man-made resources grow and are also built. Indonesia even regulates land ownership through this Land Law so that land use or management can be carried out carefully in the present and in the future. Land issue is a problem that concerns the most basic rights of the people. Besides having economic value, land also functions socially, therefore private interests in the land are sacrificed for the sake of public interest. This is done by relinquishing the right to land with compensation that 
is not only in the form of money but also in the form of land or other facilities. Philosophically, land was not given to individuals from the beginning. ${ }^{1}$

According to Article 16 of Law Number 5 of 1960 concerning Basic Agrarian Regulations or commonly referred to as the Basic Agrarian Law, hereinafter abbreviated as UUPA, regulates land rights that can be granted to citizens in the form of the most important, namely: Ownership rights, land use rights, building use rights, usage rights, lease rights, land opening rights, rights to collect forest products and other rights that are not included in the aforementioned rights which will be stipulated by law and rights - rights that are temporary in nature as stated in Article 53 of the UUPA.

This means that the economic value of land rights will be different from the rights attached to the land, thus the compensation given to the land also determines how much must be received with the different rights, however the state has the authority to carry out development as regulated. in statutory regulations either by revocation of rights or by land acquisition.

The process of land acquisition will never be separated from the problem of compensation, for this reason it is necessary to conduct a research in advance of all information and data submitted in making an assessment (apprisal) of compensation. If an agreement has been reached regarding the form and amount of compensation, then the compensation payment will be made then proceed with the release or transfer of the rights to the land concerned.

Deliberation is not always a solution to resolving land problems between the government and the holders of land rights, while the land will be used for public interest, it can be pursued by revoking land rights as regulated in Law Number 20 of 1961 concerning Revocation of Rights. Land and the objects on it. Development that is intended for the public interest today demands the fulfillment of the need for land acquisition quickly.

The deliberation mechanism which is supposed to be a means of finding a middle way in determining the amount of compensation often does not reach an agreement and therefore for reasons of public interest, the government through the land acquisition committee can determine the amount of compensation unilaterally and then entrust it to the local district court through custody of compensation. loss or often called the term consignment.

Compensation in PP No. 71 of 2012 concerning PPTBPUKU which is applied is different from the custody regulated in the Civil Code hereinafter abbreviated as KUHPdt, where in the KUHPdt a consignment or deposit of money can be made if previously there was a legal relationship between the parties. Whereas in Government Regulation No. 71/2012 concerning PPTBPUKU, on the contrary, consignment is applied when an agreement between the parties is not reached, there is no legal relationship at all between the parties. The difference in the concept of consignment implementation indicates that PP No. 71 of 2012 concerning PPTBPUKU, favors foreign investors rather than the fate of the community whose land must be taken for development, often in the name of the public interest. If the person in possession of the receivable refuses payment from the debtor, then the party owed can make cash payment of the debt by offering a payment made by the bailiff accompanied by 2 (two) witnesses. If the debtor refuses to accept payment, the money is deposited in the cash

${ }^{1}$ Soedharyo Soimin. 2004. Status of Land Rights and Acquisition, Sinar Grafika, Jakarta, p. 82 
registrar of the District Court as a deposit / consignment. The offer and deposit must be legalized by a judge's order. By carrying out a consignment, it will be freed from the obligation of being a debtor, because consignment can be equated with making payments. However, all this must be done in a manner regulated by statutory regulations.

Based on the description of the background above, the writer feels interested in conducting research which is objected to answer following questions: (1) How the consignment process of depositing money at the District Court as a form of settlement of compensation for land acquisition for the Sumatra toll road at the Kalianda District Court? (2) How is the legal protection for the consignment of depositing money at the District Court as a form of settlement of compensation for land acquisition for the Sumatra toll road at the Kalianda District Court?

\section{METHODS}

The problem in this research is through a normative juridical approach in order to obtain a correct and objective research result. The normative juridical research approach is an approach by examining the principles, norms, rules related to the problem to be studied. The data used in this study include secondary data, namely: data obtained from the library literature study. This data is obtained by studying, reading, citing and analyzing the related literature, principles and theories of law and regulations related to the subject of this research. Furthermore, secondary data in this study consisted of three (3) legal materials: (1) Primary Legal Materials, (2) Tertiary Legal Materials.

In this study, the authors used data collection techniques based on juridical analysis methods by collecting information / data through library research (library research). Research library (library research), namely research conducted to obtain secondary data related to the author's research. In this study the authors will perform data processing with the following stages: (1) Selecting information on the Consignment Process for depositing money at the District Court as a form of settlement of compensation for land acquisition for the Sumatra toll road at the Kalianda District Court. (2) Conduct a systematic arrangement of the causes and effects of the legal consequences of depositing money in the District Court as a form of settlement of compensation for land acquisition for the Sumatra toll road at the Kalianda District Court.

\section{DISCUSSION}

1. The consignment process is depositing money at the District Court as a form of settlement of compensation for land acquisition for the Sumatra toll road at the Kalianda District Court

The signaling was carried out after the deliberation mechanism which was supposed to be a means of finding a middle way in determining the amount of compensation often failed to reach an agreement. the consignment was carried out so that government projects for the sake of continued progress. ${ }^{2}$

${ }^{2}$ Rusli, T. (2018). Analysis of the Implementation of Compensation Consignment in Land Acquisition. Progressive Justice, p. 9. 
In the consignment process for compensation begins with a request for a consignment deposit of compensation that is submitted in writing in Indonesian by the Petitioner, in this case a commitment maker official, land acquisition agency Sumatran Toll Road, land acquisition work unit, Sumatra Toll Road, Freeway, Urban and Regional Road Facilities Directorate General of Highways of the Ministry of Consignment application for compensation in accordance with article 25 of the Supreme Court Regulation Number 3 of 2016 concerning Procedures for Submitting Objections and Custody of Compensation to the District Court in Land Acquisition for Development for Public Interest.

After application for a consignment for compensation at registration, then an offer is made by the court bailiff accompanied by 2 (two) witnesses made at the residence of the respondent, if the address of the respondent's residence is not known, the offer of payment is made at the Kelurahan / Desa, Camat or other names. If the offer has been completed, the bailiff will prepare an official report regarding the willingness to accept or reject the offered compensation, signed by the bailiff, the witnesses and the respondent. If the respondent refuses to accept the compensation payment, the head of the court determines the day of trial to examine the application for custody of compensation and orders the bailiff to summon the applicant and the respondent which will be carried out on the date of the hour by making an official report about the notification that the compensation money will be deposited in Cash Registrar of the Court.

\section{Table 1. Application for Consignment of Compensation at the Class II Kalinda Court 2017-2020}

\begin{tabular}{|c|c|c|c|}
\hline No & Respondent & Consignment Register Number & $\begin{array}{c}\text { Amount of } \\
\text { Compensation Value }\end{array}$ \\
\hline 1 & Sugiyanto & $\begin{array}{l}\text { No. } 24 \text { / Pdt.P.Kons / } 2017 \text { / } \\
\text { PN.Kla. }\end{array}$ & RP. 4,925,127,507, - \\
\hline 2 & Jumadi & $\begin{array}{l}\text { No. } 24 \text { / Pdt.P.Kons / } 2017 \text { / } \\
\text { PN.Kla. }\end{array}$ & RP. 3,572,547,373, - \\
\hline 3 & Djumino & $\begin{array}{l}\text { No. } 24 \text { / Pdt.P.Kons / } 2017 \text { / } \\
\text { PN.Kla. }\end{array}$ & RP. 2,716,139,851, - \\
\hline 4 & Sarjiyo & $\begin{array}{l}\text { No. } 24 \text { / Pdt.P.Kons / } 2017 \text { / } \\
\text { PN.Kla. }\end{array}$ & RP. $2,753,784,138,-$ \\
\hline 5 & Sumarjo & $\begin{array}{l}\text { No. } 24 \text { / Pdt.P.Kons / } 2017 \text { / } \\
\text { Pn.Kla. }\end{array}$ & RP. 1,353,872,500, - \\
\hline
\end{tabular}


The consignment process for compensation at the Kalinda District Court begins with the submission of a consignment application for compensation in land acquisition for the public interest which is submitted by the official who makes land acquisition commitments for the Sumatran toll road, the Ministry of Public Works and Public Housing, the Directorate of highways, urban and road facilities area of the work unit for land acquisition for the toll road Region II, land acquisition for the Sumatran toll road having the address at Desa Jati Mulyo RT 008 RW 003 Jati Agung Subdistrict, South Lampung Regency, by attaching evidence of evidence corroborating the request.

After the application for a consignment for compensation is received by the District Court, then the Registrar orders the Bailiff to be accompanied by 2 (two) witnesses to make a notification payment to the Kelurahan / Desa or Kecamatan Office where the address of origin of the entitled party is or where the object of land acquisition is located. The bailiff informs the Lurah / Village Head that the people's land is the object of land acquisition but the owner's address is not known where the offer of compensation money is not known as guided by article 27 of the Supreme Court Regulation Number 3 of 2016 concerning Procedures for Filing Objections and Custody of Compensation to the District Court in Land Acquisition for Development for Public Interest.

Regarding the procedure for compensation consignment for one or several owners of a plot of land, buildings, plants, or objects related to land where the government agency requiring land cannot find their residence, this can cause difficulties in implementing the consignment. As a solution, these government agencies must try to find the residence of the owner of land rights whose place of residence is unknown in print and electronic media with the advertising costs borne by government agencies that require land or can announce at the Lurah / Village Office or the District Office where the land is the land acquisition is carried out for the public interest. If within 30 (thirty) days after the advertisement the place of residence is still unknown.

2. As a result of the law, the consignment was depositing money at the District Court as a form of settlement of compensation for land acquisition for the Sumatra toll road at the Kalianda District Court

Legal protection for land rights holders implies that holders of land rights have the right to protect their rights in relation to land acquisition carried out by government agencies requiring land. The concept described by Philipus M. Hadjon in his book states that the definition of legal protection for the people is related to the formulation which in the Dutch language literature reads "rechtsbescherming van de burgers tegen de overhead" and in the English literature "legal protection of the individual in relation to acts of administrative authorities ". 3

Preventive legal protection means a lot for governmental acts based on freedom of action because with preventive legal protection the government is motivated to be careful in making decisions based on discretion. 19 Legal protection is an illustration of the legal function where the law can provide justice, order, certainty, benefit, peace,

${ }^{3}$ Prof. Dr. Philipus M. Hadjon, Legal Protection for the Indonesian People, Civilization. 2007.

h. 1 . 
tranquility for all human interests in society. ${ }^{4}$ In the practice of land acquisition for the implementation of development for the public interest, compensation for buildings, plants and other objects related to land does not encounter many obstacles in determining the amount. However, the problem that often arises is regarding the determination of the amount of compensation for land rights. Between land rights holders and government agencies requiring land, it is often difficult to reach agreement in deliberations regarding the amount of compensation. Therefore, the most important element lies in how the deliberations take place so that there is an agreement so that neither party is harmed. Deliberations are carried out with kinship and no one is concerned with any party.

Holders of land rights are given legal protection against disagreements in the determination of compensation, this is regulated in Articles 17 and 18 of Presidential Regulation No. 36 of 2005. Holders of land rights can submit objections to the Regent / Mayor or governor or Minister of Home Affairs with an explanation and reasons for the objection. The Regent / Mayor or Governor or Minister of Home Affairs after hearing and studying the opinions and desires of land rights holders and the considerations of the land acquisition committee can confirm or change the decision of the land acquisition committee regarding the form and / or amount of compensation to be given. If the owner of the land rights does not accept the above settlement efforts, then a settlement proposal can be submitted by means of revoking land rights based on Law Number 20 Year 1961 concerning Revocation of Rights to Land and Objects on it. From the description above, holders of land rights can only file objections to the amount of compensation, not against land rights that will be used for public interest. Consequently, land rights holders have no other choice but to release or give up their rights to land.

If examined, the provisions of Article 17 and Article 18 of Presidential Regulation No. 36 of 2005 with the provisions of Article 17 and Article 18 of Presidential Regulation No. 36 of 2005 out of sync. This discrepancy is because Article 10 states that the Head of the Regency / City Land Acquisition Committee issues a decision regarding the amount of compensation after deliberation between government agencies requiring land and land rights holders for 120 (one hundred and twenty) days, not reaching an agreement and depositing monetary compensation. to the District Court whose jurisdiction includes the location of the land concerned, whereas Article 17 stipulates that land rights holders who do not accept the decision of the Land Acquisition Committee can submit objections to the Regent / Mayor or Governor or Minister of Home Affairs according to their authority accompanied by an explanation of the reasons and reasons for the objection. This creates legal uncertainty for land rights holders and as a result government agencies can make this asynchrony an opening to acquire land easily and of course with low compensation. In practice, consignment efforts are often taken by government agencies requiring land in order to carry out the land acquisition process. By having deposited compensation, government agencies requiring land are considered to have implemented their obligation to provide appropriate compensation to land rights holders and feel they have the right to take over land rights. It is up to the holder of land rights whether or not to take compensation to the District Court in its jurisdiction covering the location of the land concerned, it is not a matter for the Government agency requiring the land. Such actions constitute coercion of the will, unilateral treatment, deprivation of rights, arbitrary actions by

${ }^{4}$ Firmansyah, H. (2018). Legal Protection of Trademarks: Guide to Understanding the Legal Basis of Use and Protection of Trademarks. Media Pressindo. 
government agencies requiring land, and lack of respect for legal rights to land. Taking over land rights by government agencies requiring land is a deprivation of land rights in disguise, and this can be said to have overstepped the authority of the president, because taking land rights unilaterally for the public interest is the authority of the President through efforts to revoke land rights. 23 Government agencies requiring land to take land rights over land cannot be justified before an agreement is reached in deliberations regarding the form of compensation under consignment. Because consignment is justified if the holder of land rights has signed a statement of release or surrender, but does not want to receive compensation. However, if an agreement has not been reached, then the consignment cannot be considered as a basis for taking over land rights, because it does not provide legal protection for the holder of land rights. Moreover, in Presidential Regulation No. 36 of 2005, Presidential Regulation.

\section{CONCLUSION}

In the consignment process for compensation begins with a request for a consignment deposit of compensation that is submitted in writing in Indonesian by the Petitioner, in this case a commitment maker official, land acquisition agency Sumatran Toll Road, land acquisition work unit, Sumatra Toll Road, Freeway, Urban and Regional Road Facilities Directorate General of Highways of the Ministry of Consignment application for compensation in accordance with article 25 of the Supreme Court Regulation Number 3 of 2016 concerning Procedures for Submitting Objections and Custody of Compensation to the District Court in Land Acquisition for Development for Public Interest. After application for a consignment for compensation at registration, then an offer is made by the court bailiff accompanied by 2 (two) witnesses made at the residence of the respondent, if the address of the respondent's residence is not known, the offer of payment is made at the Kelurahan / Desa, Camat or other names. If the offer has been completed, the bailiff will prepare an official report regarding the willingness to accept or reject the offered compensation, signed by the bailiff, the witnesses and the respondent. If the respondent refuses to accept the compensation payment, the head of the court determines the day of trial to examine the application for custody of compensation and orders the bailiff to summon the applicant and the respondent which will be carried out on the date of the hour by making an official report about the notification that the compensation money will be deposited in Cash Registrar of the Court.

By depositing compensation to the District Court by government agencies requiring land, it does not provide legal protection for land holders as long as there has been no agreement manifested in the signing of a statement letter for the release or transfer of land rights. This can be categorized as an arbitrary act, because there is no provision regarding the permissibility of government agencies requiring land to take rights over the land of the land bag right holder after depositing compensation to the District Court. There is a discrepancy in the Regulations in Presidential Regulation No. 36 of 2005 as amended by Presidential Regulation No. 65 of 2006, so it is necessary to conduct a review of the Presidential Regulation. The unsynchronization of these arrangements has resulted in different interpretations and this has triggered problems in land acquisition for the public interest. It is deemed necessary to increase the Presidential Regulation regarding land acquisition for public interest into a Law. This is because in Presidential Regulation No. 36 of 2005 as amended by Presidential Regulation No. 65 of 2006 regulates human rights in the form of rights and obligations of land rights holders in land acquisition for the implementation of development for 
the public interest. This is because in Presidential Regulation No. 36 of 2005 as amended by Presidential Regulation No. 65 of 2006 regulates human rights in the form of rights and obligations of land rights holders in land acquisition for the implementation of development for the public interest. This is because in Presidential Regulation No. 36 of 2005 as amended by Presidential Regulation No. 65 of 2006 regulates human rights in the form of rights and obligations of land rights holders in land acquisition for the implementation of development for the public interest.

\section{SUGGESTION}

The Supreme Court revises the Supreme Court Regulations Republic of Indonesia Number 3 of 2016 concerning Submission Procedures Objections in Custody of Compensation to the District Court in Land Procurement for Development for Public Interest, with amending the article regarding the payment offer made by bailiffs are replaced with notification of storage of compensation money, because at the time of deliberation the entitled parties had compensated for the damages knowing if the party entitled to refuse the results of the amendment deliberation loss then the compensation money will be deposited with the District Court local.

People who file an objection to the results of the compensation deliberations that cause obstruction to the submission of the application for compensation for consignment, then in this case the Supreme Court must change the period for filing an objection in the Supreme Court Regulation Number 3 of 2016 which was originally a maximum of 14 (fourteen) becomes 7 (seven) days after the results of deliberation for compensation. In order not to wait too long and a consignment application for compensation can be submitted by the land acquisition executive committee to the District Court.

\section{BIBLIOGRAPHY}

\section{A. Books}

Soedharyo Soimin. 2004. Status of Land Rights and Acquisition, Sinar Grafika, Jakarta

Philipus M. Hadjon, Legal Protection for the Indonesian People, Civilization. 2007.

\section{B. Journal Articles}

Rusli, T. (2018). Analysis of the Implementation of Compensation Consignment in Land Acquisition. Progressive Justice.

Firmansyah, H. (2018). Legal Protection of Trademarks: Guide to Understanding the Legal Basis of Use and Protection of Trademarks. Media Pressindo.

Marlijanto, SD (2010). Consincation Of Indemnity In Land Procurement For General Interest (Study of Land Acquisition for the Construction of Semarang - Solo Highway Project in Semarang Regency) (Doctoral dissertation, Diponegoro University). 


\section{Regulations}

The 1945 Constitution of the Republic of Indonesia Amendments

Code of Civil law.

Law No. 5/1960 on Basic Agrarian Regulations.

Law Number 20 Year 1961 concerning Revocation of Land Rights and Objects on it.

Law Number 2 of 2012 concerning Land Acquisition for Development for Public Interest

Government Regulation Number 24 of 1997 concerning Registration of Land Rights

Presidential Regulation Number 65 of 2006 concerning Land Acquisition for Implementation Development for Public Interest

Presidential Regulation Number 71 of 2012 concerning Implementation of Land Acquisition for Development for Public Interest

Presidential Decree Number 55 of 1993 concerningLand Acquisition for Implementation of Development for Public Interest

Supreme Court Regulation Number 3 of 2016 concerning Procedures for filing objections and custody of compensation to the District Court in Land Procurement for Development for Public Interest. 